EVIDENCE OF THE EXISTENCE OF A PRE-OPSONIN IN NORMAL SERUM, CONVERTIBLE INTO ACTIVE OPSONIN BY THE ADDITION OF ANY MICROORGANISM - LOWERING AND ULTIMATE SUP. PRESSION OF OPSONIC POWER OF NORMAL SERUM TO ALL ORGANISMS BY THE ADDITION OF ONE.

By WARRINGTON YORKE, M.B., B.Ch., Holt Fellow in Physiology, AND CHARLES HAROLD SMITH, M.B., B.Ch., Holt Fellow in Pathology.

From the Thompson-Yates and Fohnston Laboratories, University of Liverpool.

(Received November 29th, 1906.)

It is now a well-known fact that the sera of the higher animals contain opsonin for many different bacteria. Thus, staphylococci and streptococci and tubercle, typhoid, colon, anthrax, tetanus, diphtheria, and many other bacilli, when treated with normal human serum, are rendered susceptible to phagocytosis by leucocytes.

One of the questions which a knowledge of this fact immediately suggests is, whether the action of the serum is due to one substance in it capable of acting on almost any micro-organism with which it may come in contact, or whether it is the result of an enormous number of distinct bodies, each of which opsonises only one particular kind of bacteria or group of bacteria. In other words, is the generally accepted view that there exist in normal serum specific opsonins for each different micro-organism correct: or is there a single body, pre-opsonin, which, under the stimulus of the presence of a microorganism, produces an active opsonin for that organism?

The current view, that in normal serum a high degree of specificity exists, depends upon evidence of the following nature.

In the first place, an individual may have a high opsonic index for one organism and be normal to all others, or he may be low to one bacterium and normal to the remainder. For example, the inoculation of a normal man with tuberculin will cause a rise or fall in his tuberculo-opsonic index, without any alteration in his opsonic 
power for other organisms. Again, persons suffering from some such disease as acne or chronic tuberculosis often have an abnormal opsonic index for either staphylococcus or tubercle, whereas their other indices are normal.

In the second place, it has been noticed that the addition of tubercle bacilli to normal human serum, and incubation of the mixture at $37^{\circ} \mathrm{C}$. for a period, will deprive the serum, when separated from the bacilli by prolonged centrifugalization, of its tuberculo-opsonin, whereas the opsonin for staphylococci remains unaffected; and conversely, serum treated in a similar manner with staphylococci, loses its staphylococcic opsonin, but retains its tuberculo-opsonin. ${ }^{r}$

From observations of this kind it has been argued that, if the serum of a tubercular patient can have a high tuberculo-opsonic index and a normal one for anthrax or typhoid bacilli, and if the addition of staphylococci to serum reduces its opsonic index for this organism but not for tubercle bacilli, then there must be present in serum a large number of specific opsonins.

On reflection, however, it seems hardly probable that normal serum contains an enormous number of different opsonins, all more or less distinct from one another, each present only for the purpose of defending the body from its corresponding bacterium, which it is quite probable it may never be required to do.

With a view to investigating this point more fully we performed a number of experiments of the following nature. Various amounts of different micro-organisms were suspended in separate portions of normal human serum, and after longer or shorter periods of incubation were thrown down by prolonged centrifugalization. The opsonic indices of the supernatant serum for different bacteria were then estimated.

\section{Experimental Results}

The following are some of the results :-

Experiment I.-Two portions of the same normal human serum were taken, $\mathrm{A}$ and B. Living anthrax bacilli were added to $A$, and both $A$ and $B$ were then placed in the 
incubator at $37^{\circ} \mathrm{C}$. for 15 minutes. The bacteria were then thrown down as a deposit by prolonged centrifugalization. The opsonic index of the supernatant serum A was then determined for anthrax baccilli and for staphylococci, the other portion, B, being used as a control.

\begin{tabular}{cccccccc} 
& \multicolumn{5}{c}{$\begin{array}{c}\text { No. of bacteria } \\
\text { phagocytosed }\end{array}$} & $\begin{array}{c}\text { No. of leucocytes } \\
\text { counted }\end{array}$ & Index \\
Anthrax- & & & & & & & \\
Control serum & $\ldots$ & $\ldots$ & 67 & $\ldots$ & 50 & $\ldots$ & I \\
Treated serum & $\ldots$ & $\ldots$ & 19 & $\ldots$ & 50 & $\ldots$ & 3 \\
StaphyLococcus- & & & & & & & \\
Control serum & $\ldots$ & $\ldots$ & 210 & $\ldots$ & 50 & $\ldots$ & I \\
Treated serum & $\ldots$ & $\ldots$ & 91 & $\ldots$ & 50 & $\ldots$ & 4
\end{tabular}

Experiment II.-The period of incubation was prolonged to 45 minutes.

\begin{tabular}{rlrrrrrrr} 
& \multicolumn{5}{c}{$\begin{array}{c}\text { No. of bacteria } \\
\text { phagocytosed }\end{array}$} & $\begin{array}{c}\text { No. of leucocytes } \\
\text { counted }\end{array}$ & Index \\
Anthrax- & & & & & & & \\
Control serum & $\ldots$ & $\ldots$ & 59 & $\ldots$ & 50 & $\ldots$ & I \\
Treated serum & $\ldots$ & $\ldots$ & 17 & $\ldots$ & 50 & $\ldots$ & 28 \\
StaphyLococcus- & & & & & & & \\
Control serum & $\ldots$ & $\ldots$ & I54 & $\ldots$ & 50 & $\ldots$ & I \\
Treated serum & $\ldots$ & $\ldots$ & 23 & $\ldots$ & 50 & $\ldots$ & 215
\end{tabular}

Experiment III.-In this experiment the sera were allowed to stand for two hours at the temperature of the room instead of being placed in the incubator.

\begin{tabular}{ccrrrrrrr} 
& \multicolumn{5}{c}{$\begin{array}{c}\text { No. of bacteria } \\
\text { phagocytosed }\end{array}$} & $\begin{array}{c}\text { No. of leucocytes } \\
\text { counted }\end{array}$ & Index \\
Anthrax- & & & & & & & \\
Normal serum & $\ldots$ & $\ldots$ & 89 & $\ldots$ & 50 & $\ldots$ & I \\
Treated serum & $\ldots$ & $\ldots$ & 4 & $\ldots$ & 50 & $\ldots$ & $\circ$ \\
StAPHYLococcus- & & & & & & & \\
Normal serum & $\ldots$ & $\ldots$ & 220 & $\ldots$ & 50 & $\ldots$ & I \\
Treated serum & $\ldots$ & $\ldots$ & 46 & $\ldots$ & 50 & $\ldots$ & 2
\end{tabular}

Experiment $I V$. - In this experiment staphylococci were added to the serum instead of anthrax, and the mixture was incubated 45 minutes.

Anthrax-

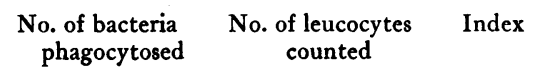

$\begin{array}{llllllll}\text { Normal serum } & \ldots & \ldots & \text { I2I } & \ldots & 50 & \ldots & \text { I }\end{array}$

$\begin{array}{llllllll}\text { Treated serum } & \ldots & \ldots & 9 & \ldots & 50 & \ldots & \circ\end{array}$

Staphylococcus-

$\begin{array}{llllllll}\text { Normal serum } & \ldots & \ldots & 430 & \ldots & 50 & \ldots & \text { I }\end{array}$

$\begin{array}{llllllll}\text { Treated serum } & \ldots & \ldots & 9 & \ldots & 50 & \ldots & \circ\end{array}$ 
Experiment $V$.- Here anthrax bacilli, - tilled-by heating at $100^{\circ} \mathrm{C}$. for 15 minutes and then, after cooling, heated again at $100^{\circ} \mathrm{C}$. for 15 minütes, were added to serum, and the experiment continued as in $\mathrm{I}$.

A When incubated with dead anthrax for 15 minutes.

Anthrax-

No. of bacteria No. of leucocytes Index

$\begin{array}{lllllllll}\text { Control serum } & \ldots & \ldots & 45 & \ldots & 40 & \ldots & \text { I }\end{array}$

$\begin{array}{llllllll}\text { Treated serum } & \ldots & \ldots & \text { I } & \ldots & 40 & \ldots & \circ\end{array}$

STAPHYLOCOCCUS-

$\begin{array}{lllllllll}\text { Control serum } & \ldots & \ldots & \text { I } 18 & \ldots & 40 & \ldots & \text { I }\end{array}$

$\begin{array}{lllllllll}\text { Treated serum } & \ldots & \ldots & 36 & \ldots & 40 & \ldots & 3\end{array}$

B When incubated with dead anthrax for 45 minutes.

ANTHrax-

$\begin{array}{ccc}\begin{array}{c}\text { No. of bacteria } \\ \text { phagocytosed }\end{array} & \begin{array}{c}\text { No. of leucocytes } \\ \text { counted }\end{array} & \text { Index }\end{array}$

$\begin{array}{lllllllll}\text { Control serum } & \ldots & \ldots & 45 & \ldots & 40 & \ldots & \text { I }\end{array}$

$\begin{array}{llllllll}\text { Treated serum } & \ldots & \ldots & \circ & \ldots & 40 & \ldots & \circ\end{array}$

STAPHYLOCOCCUS-

$\begin{array}{lllllllll}\text { Control serum } & \ldots & \ldots & \text { II8 } & \ldots & 40 & \ldots & \text { I }\end{array}$

$\begin{array}{lllllllll}\text { Treated serum } & \ldots & \ldots & 6 & \ldots & 40 & \ldots & \circ\end{array}$

Experiment VI.-Dead tubercle bacilli were added to serum, and the mixture incubated for 15 minutes. Then, after separating the micro-organisms by means of the centrifuge, the opsonic power of the supernatant serum was estimated for tubercle and staphylococci.

Tubercle-

$$
\begin{array}{ccc}
\begin{array}{c}
\text { No. of bacteria } \\
\text { phagocytosed }
\end{array} & \begin{array}{c}
\text { No. of leucocytes } \\
\text { counted }
\end{array} & \text { Index }
\end{array}
$$

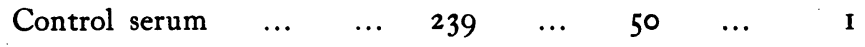

$\begin{array}{llllllll}\text { Treated serum } & \ldots & \ldots & 49 & \ldots & 50 & \ldots & \cdot 2\end{array}$

STAPHYLOCoccus-

$\begin{array}{lllllllll}\text { Control serum } & \ldots & \ldots & 376 & \ldots & 50 & \ldots & \text { I }\end{array}$

$\begin{array}{llllllll}\text { Treated serum } & \ldots & \ldots & 140 & \ldots & 50 & \ldots & 37\end{array}$

In all the preceding observations there was no definite relation between the amount of serum used and the quantity of bacteria added. It varied in each experiment, a quantity of the bacteria obtained from a growth on agar being used in each case, except Experiment VI.

Experiment VII.-A strong emulsion of anthrax bacilli was made in 9 per cent. $\mathrm{NaCl}$. This was heated at $100^{\circ} \mathrm{C}$. for 30 minutes. The bacilli were then thrown down 
as a deposit by means of the centrifuge, and washed with 9 per cent. $\mathrm{NaCl}$. This was repeated three times. These washed dead bacilli were then made up into a strong emulsion in 9 per cent. $\mathrm{NaCl}$, and added to three separate quantities of normal serum in the following proportions-
A I part of emulsion to 19 parts of serum.
B 5 parts of emulsion to 15 parts of serum.
C Io parts of emulsion to Io parts of serum.

These were then incubated at $37^{\circ} \mathrm{C}$. for 15 minutes, and after centrifugalization, the opsonic index of the supernatant sera for anthrax and staphylococci was determined as before. In each case the control sera were diluted equally with 9 per cent. $\mathrm{NaCl}$.

A Anthrax-

$\begin{array}{ccc}\begin{array}{c}\text { No. of bacteria } \\ \text { phagocytosed }\end{array} & \begin{array}{c}\text { No. of leucocytes } \\ \text { counted }\end{array} & \text { Index }\end{array}$

$\begin{array}{rccccccc}\text { Control serum } & \ldots & \ldots & 222 & \ldots & 50 & \ldots & \text { I } \\ \text { Treated serum } & \ldots & \ldots & \text { I70 } & \ldots & 50 & \ldots & 7 \\ \text { PHYLOcoccus- } & & & & & & & \\ \text { Control serum } & \ldots & \ldots & 382 & \ldots & 50 & \ldots & \text { I } \\ \text { Treated serum } & \ldots & \ldots & 227 & \ldots & 50 & \ldots & .6\end{array}$

B Anthrax-

$\begin{array}{lllllllll}\text { Control serum } & \ldots & \ldots & \mathbf{1} 73 & \ldots & 50 & \ldots & \text { I }\end{array}$

$\begin{array}{lllllllll}\text { Treated serum } & \ldots & \ldots & 58 & \ldots & 50 & \ldots & 3\end{array}$

Staphylococcus- $\quad \ldots$

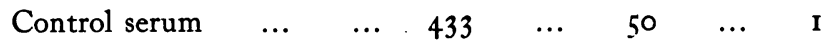

$\begin{array}{lllllllll}\text { Treated serum } & \ldots & \ldots & \text { I } 79 & \ldots & 50 & \ldots & 4\end{array}$

C Anthrax-

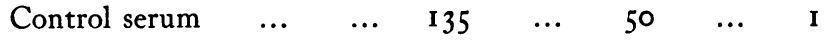

$\begin{array}{lllllllll}\text { Treated serum } & \ldots & \ldots & \mathbf{1} 4 & \ldots & 50 & \ldots & \cdot \mathbf{I}\end{array}$ STAPHYLOCOCCUS-

$\begin{array}{lllllllll}\text { Control serum } & \ldots & \ldots & 369 & \ldots & 50 & \ldots & \text { I }\end{array}$

$\begin{array}{llllllll}\text { Treated serum } & \ldots & \ldots & \text { I65 } & \ldots & 50 & \ldots & 4\end{array}$

Experiment VIII.-A strong emulsion of washed dead anthrax bacilli was prepared as in Experiment VII. Equal quantities of this were added to two equal portions of normal serum, $A$ and $B$.
A was incubated for 30 minutes at $37^{\circ} \mathrm{C}$.
B was incubated for 60 minutes at $37^{\circ} \mathrm{C}$.

Then, after throwing down the bacteria by means of the centrifuge, the supernatant sera were tested for opsonins as before with staphylococci and anthrax. The control sera were diluted to a similar extent with 9 per cent. $\mathrm{NaCl}$, and were placed in the incubator for corresponding periods. 


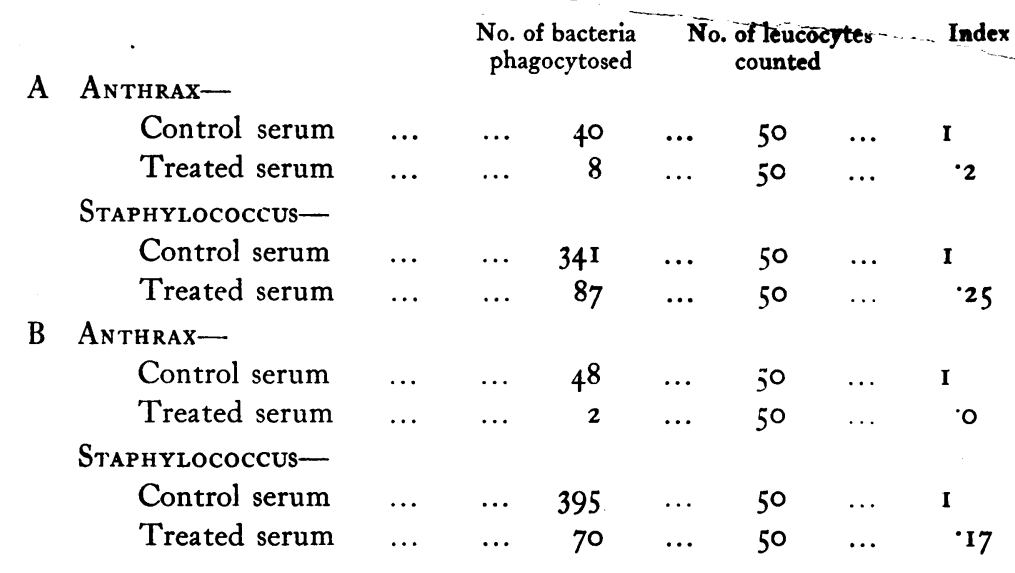

From these experiments it would seem that it is impossible to separate from normal serum any one opsonin by adding the particular microbe to it, and at the same time leave the opsonins corresponding to other micro-organisms intact. It appears that adding a quantity of any microbe to serum, will enormously diminish its opsonic power for other organisms, as well as for that corresponding to the bacteria added. The fall in the opsonic index is, apparently, general, in contradiction to what one would expect if there were a number of distinct opsonins in the serum.

These facts are more easily explicable on the supposition that there is in normal serum a single body from which, under the adequate stimulation of certain bacteria, there can be split off the particular opsonin which will combine with them.

Normal serum will no longer exert an opsonic effect upon bacteria, as measured by Wright's method, after it has been heated at $60^{\circ} \mathrm{C}$. for 15 minutes. Immune opsonins, on the contrary, are but little affected by such a temperature.

It has been shown that cocci, which have been suspended in normal serum for some time, are, even after heating at $60^{\circ} \mathrm{C}$. for several hours, readily ingested by leucocytes. ${ }^{1}$

From these observations it may be argued that there is present in normal serum a substance 'Pre-opsonin.' This, when it comes in contact with any kind of bacteria splits off from itself the specific 
opsonin necessary for the bacterium. The greater the number of any kind of bacteria added to any portion of serum, the more specific opsonin it is necessary for the pre-opsonin to form. This must necessarily mean a lessening in the quantity of pre-opsonin present. Hence, less quantities of other specific opsonins are formed when other organisms are added to the serum. This will account for the general lowering of the opsonic indices which we noted in the foregoing experiments.

The specific opsonin which becomes attached to the bacteria may be the same thing as the immune opsonin, since, as we have seen, both are unaffected by heating to $60^{\circ} \mathrm{C}$.

The specific rise in the opsonic index which is noticed after the injection of a vaccine may be explained by assuming that certain of the opsonin-forming cells are stimulated to form a specific opsonin instead of, or as well as, the general pre-opsonin which they are normally putting out into the serum.

We have noticed that after the injection of a healthy man with anti-tetanic serum a specific rise in the tetano-opsonic index was followed by a general fall. Thus the staphylo-, tuberculo-, and tetano-opsonic indices, all fell considerably below normal. A similar, though less marked, general depression was observed after injection of anti-streptococcic and anti-diphtheritic sera. The tuberculoopsonic indices of nine patients inoculated with anti-diphtheritic serum, were all found to be low. ${ }^{2}$

It is possible that these anti-toxic and anti-bacterial sera resulted in the formation of specific anti-opsonins.

Hektoen and Ruediger mention a number of non-specific anti-opsonins, e.g., $\mathrm{CaCl}_{2} \mathrm{BaCl}_{2}, \mathrm{NaHCO}_{3}$, lactic acid, alcohol, etc. ${ }^{3}$

That these specific anti-opsonins and non-specific anti-opsonins result in a general fall in the opsonic action of the blood, seems to favour the view that, in normal serum, there are probably not a considerable number of distinct opsonins. 